\title{
Land Rights in Rural China since 1978
}

Reforms, Successes, and Shortcomings(

\section{Thomas Vendryes}

\section{(2) OpenEdition}

\section{Journals}

Édition électronique

URL : http://journals.openedition.org/chinaperspectives/5345

DOI : 10.4000/chinaperspectives.5345

ISSN : 1996-4617

Éditeur

Centre d'étude français sur la Chine contemporaine

Édition imprimée

Date de publication : 15 décembre 2010

ISSN : 2070-3449

Référence électronique

Thomas Vendryes, «Land Rights in Rural China since 1978 », China Perspectives [En ligne], 2010/4 |

2010, mis en ligne le 01 décembre 2013, consulté le 28 octobre 2019. URL : http://

journals.openedition.org/chinaperspectives/5345; DOI : 10.4000/chinaperspectives.5345

(C) All rights reserved 


\title{
Land Rights in Rural China
} since 1978

\author{
Reforms, successes, and shortcomings (1)
}

\section{THOMAS VENDRYES}

ABSTRACT: Since 1978, changes in rural land policies have constituted a critical dimension in the evolution of the Chinese economy toward liberalisation and marketisation. This paper aims at reviewing the institutional changes that took place in Chinese rural areas, with a particular focus on two essential dimensions of their dynamics: the central state and regulations, and local rural Chinese citizens' interests.

\section{Introduction}

W hen Deng Xiaoping initiated a series of economic and social reforms in 1978, rural society reorganisation constituted a critical first step. To quote Barry Naughton, ${ }^{(2)}$ "It was in the countryside that reforms succeeded first, and it was the dramatic success of rural reforms that cleared the way for continuing and progressively more profound change."

The very core of this founding reform was institutional. A significant number of rights were transferred from collective structures to farm households, and this engaged a dynamics of extension of individual rights that is still far from being over today.

Over this period, the importance of rural reforms cannot be overstated. In 1978, more than 82 percent of the population, almost 800 million people, was rural, while agriculture employed 70.5 percent of Chinese workforce. Thirty years later, more than 55 percent of the population, close to 730 million people, was considered rural, while agriculture still represented 40.8 percent of employment. ${ }^{(3)}$ Land was and remains a major element of most of Chinese people's daily lives and a decisive determinant of Chinese economic performance. This importance is well acknowledged by the central authorities: in January 2010, for the seventh consecutive year, Document No. 1, jointly issued by the Central Committee of the Communist Party of China (CCPCC) and the State Council of the National's People Congress (SCNPC), was dedicated to rural issues and land rights problems.
This article aims at recalling the main steps in the evolution of institutional arrangements over rural land, and at identifying their main consequences, successes, and shortcomings. Its main objective is to summarise and discuss two dimensions of research on land rights issues in rural China that have not been synthesised by previous literature reviews: it will provide an extended inventory of the laws and regulations on rural land rights in China, and discuss existing research on the local level determinants of actual land rights institutional arrangements in Chinese villages. The main objective is to emphasise and understand the striking discrepancy between central regulations on rural land and the actual functioning of local land institutions.

The first part of the paper will describe the key official regulations on rural land as well as the actual functioning of land arrangements at the local level, while the second section will review the empirical studies on these institutions, with a special focus on the most recent period.

\section{Rural land in China: National regulations and local practices}

In 1978, the dynamics of collectivisation engaged in 1949 after the founding of the People's Republic of China (PRC)

1. This paper is part of a research project on land rights issues in rural China funded by the French Development Agency (AFD).

2. Barry Naughton, The Chinese Economy: Transitions and Growth, Cambridge, MIT Press, 2007, p. 88.

3. National Bureau of Statistics of China (NBS), China Statistical Yearbook, Beijing, China Statistics Press, 2009. 
was reversed, and a movement of increased individualisation began. This section first briefly recalls the organisation of rural China before 1978, and then delineates the evolution of official laws and regulations on rural land during the reforms.

\section{The dynamics of collectivisation: 1949 - 1978}

When the CCP seized power in 1949, to a great extent with peasant support, one of its first policies was the Land Reform Law of June 1950, ${ }^{(4)}$ which redistributed land from landlords and rich peasants to poorer ones. By 1952, close to a half of all agricultural land was redistributed, ${ }^{(5)}$ with roughly 60 percent of the farmers, 300 million people, being net winners. ${ }^{(6)}$ This law gave extended land rights to farmers, including ownership, use, and transfer rights guaranteed by land ownership certificates. This first reform then asserted private property over evenly distributed land.

However, during the First Five-Year Plan, starting in 1953, rural people were first encouraged and then forced to join collectivist structures. In 1955, the CCPCC published its Decisions on Agricultural Cooperation, made into law by the SCNPC in 1956 through the Charter of Agricultural Production Cooperatives. These documents respected private ownership of rural land, but encouraged peasants to organise production collectively. However, the same year, the National People's Congress (NPC) approved the Charter of Advanced Agricultural Production Cooperatives, which explicitly stated that private property must be abolished.

Events accelerated at the end of the 1950s. Disappointed with the First Five-Year Plan, Mao Zedong militated for a Great Leap Forward to a communist society, which was officially endorsed by the CCPCC in May 1958. As for agriculture, it led to a complete change in the scope of collectivisation. ${ }^{(7)}$ The new collective units, the People's Communes, gathered together, on average, as many as 5,500 households ${ }^{(8)}$ and private rights and privacy were considerably reduced. By the end of the 1950s, 90 percent of rural households belonged to these collectivist structures.

As early as 1961, the manifest failure of the Great Leap Forward led to important adjustments embodied, in respect of agriculture, in the Sixty Articles on Agriculture approved by the CCPCC on March 1961, which remained the basis for rural and agricultural organisation until 1978. ${ }^{(9)}$ Private plots and markets were authorised anew, while the collective management of agricultural production was decentralised at the level of production teams or brigades of around 45-50 households. The scope of collectivism was then reduced, while a marginal private economy was tolerated. This equilibrium prevailed until 1978, when, two years after Mao's death, Deng Xiaoping and his supporters eventually rose to the higher reaches of the government and promoted radically new economic policies for rural China.

\section{State policies and local experiments: The founding years of the Household Responsibility System (1978-1986)}

At the very outset of the reforms, two main levels of decision reshaped the organisation and functioning of rural areas: if the state played a key role, the main innovations came from grass-root villages. ${ }^{(10)}$

The CCPCC launched rural reforms in December 1978 by enhancing the 1961 adjustment policies. The collective organisation of agriculture was maintained, but the parallel private economy was expanded. The most detrimental aspects of central planning were also reformed. State prices were corrected in favour of agriculture, while the constraints of local autarky were relaxed. Finally, the rural People's Communes were reformed before being eventually dismantled in 1984.

The most important changes, however, come from local experiments in Anhui province, ${ }^{(11)}$ where some localities decided to lease farmland to households. Despite the absence

4. All legal documents mentioned are summarised in Appendix, with links to resources.

5. Nicholas Lardy, "Economic Recovery and the 1st Five-Year Plan," in Roderick MacFarquhar and John Fairbank (eds.), The Cambridge History of China, Volume 14, The People's Republic, Part 1: The Emergence of Revolutionary China, 1949-1965, Cambridge, Cambridge University Press, 1987, p. 153.

6. Ping Li and Roy Prosterman, "From Collective to Household Tenure: China and Elsewhere," in Roy Prosterman et al. (eds.), One Billion Rising: Law, Land and the Alleviation of Global Poverty, Leiden, Leiden University Press, 2009, p. 283.

7. See Nicholas Lardy, "The Chinese Economy Under Stress, 1958-1965," in Roderick MacFarquhar and John Fairbank (eds.), The Cambridge History of China, Volume 14, The People's Republic, Part 1: The Emergence of Revolutionary China, 1949-1965, Cambridge, Cambridge University Press, 1987, pp. 363-367.

8. Ibid., p. 365

9. Ibid., pp. 388-391.

10. A synthetic review can be found in the first chapter of Louis Putterman, Continuity and Change in China's Rural Development: Collective and Reform Eras in Perspective, New York and 0xford, Oxford University Press, 1993, pp. 9-59, while a more complete description is provided by Robert Ash, "The Evolution of Agricultural Policy," The China Quarterly, vol. 116, 1988, pp. 529-555.

11. They are described at length by Qinghe Huang, "Land Policy in Rural China in Retrospect, and New Problems," in Land Tenure Center of University of Wisconsin-Madison (ed.), Transition of China's Rural Land System, Papers from the International Symposium on Rural Land Issues in China, Land Tenure Center of University of Wisconsin-Madison, 1995, pp. 3-18, and in Chapter 6 of Dali Yang, Calamity and Reform in China: State, Rural Society, and Institutional Change since the Great Leap Famine, Stanford, Stanford University Press, 1996, pp. 144-179. 
of approval from higher-level authorities, it is estimated that 90 percent of Anhui production teams contracted out farmland by 1980. Facing this fait accompli, CCPCC Document No. 75 legalised the system in 1980, but only where it was already practiced. This immediately led to a tremendous expansion of the system, which was finally endorsed by CCPCC 1982 Document No. 1.

The functioning of this new system was clarified by a series of Documents No. 1, from 1982 to 1986, and was finally legally defined by the Land Management Law of 1986, based on the new Constitution of 1982. After eight years of experiments and legal evolution, the "Household Responsibility System" (HRS) was then set up in 1986.

\section{The Household Responsibility System: 1986-1998}

The founding principle of land status in China lies in the socialist nature of its state: as land is a mean of production, its ownership is collective. In urban areas, land is owned by the state. In rural areas, agricultural land is owned by rural collectives, while "mineral resources, waters, forests, mountains, grassland, unreclaimed land, beaches, and other natural resources are owned by the State." ${ }^{(12)}$

The basis of the HRS was introduced in Article 9 of the 1986 Land Management Law: land can be allocated to individuals or units for use and management. Each responsible individual or unit has to deliver a quota or to pay taxes, but is free to dispose of the surplus. According to the 1984 Document No. 1, the contract duration is 15 years, and rural individuals are granted land transfer rights. Farmers' land rights are then supposed to be secure and extended.

This general framework, however, is locally implemented with considerable variance, as the central state has little power to monitor local authorities, and as rural individuals lack effective means to defend their rights. A series of general characteristics can nevertheless be drawn.

First, as rural land is collectively owned, all rural citizens are entitled to it. As a consequence, landlessness is virtually absent, ${ }^{(13)}$ and land appears to serve as a safety net for rural people. $^{(14)}$

Second, despite state efforts, farmers' rights seldom remain unchallenged, and land transfers take place predominantly through administrative but illegal ways rather than through market processes, as stressed by investigations carried out in the 1990s, especially by James Kai-sing Kung. ${ }^{(15)}$ As a consequence, land remains allocated on a more or less egalitarian way. However, village-land reallocation creates insecurity for farmers, and can lead to allocative inefficiency, as will be discussed later.

The actual functioning of the HRS at the local level remained, in the 1980s and 1990s, quite removed from state laws and regulations. Peasants' actual rights were less extended and secure than their legal and official rights. Because of this discrepancy, central authorities resumed intense legal and regulatory activity in this domain at the end of the 1990s.

\section{The second wave of reforms: 1998 to today}

With the revision of the 1986 Land Management Law, 1998 marked a significant renewal of political interest in rural land issues, which culminated with the 2007 Property Law and with seven consecutive Documents No. 1, from 2004 to 2010, dedicated to this topic. The general objective was to further extend and secure peasants' rights over their land.

Central authorities have been especially concerned with establishing secure rights in the long term for Chinese farmers. The first move in that direction was constituted by the CCPCC 1993 Document No. 11, which extended farmers' land rights to 30 years. It was followed, in 1997, by Document No. 16, which strictly limited village land reallocation or taking. However, these regulations remained declarations of principles, as they lacked actual implementation procedures.

They were followed by a series of laws in the years 19982007. In 1998, the 1986 Land Management Law was revised, and then completed in 2002 by a Law on Land Contracts in Rural Areas. Finally, the very important Property Law, which includes dispositions of rural land rights, was passed in 2007.

These laws reasserted the principles of the 1993 and 1997 documents, and progressively extended and strengthened farmers' rights. ${ }^{(16)}$ As for land rights security, the revised

12. 1982 Constitution, Articles 9 and 10.

13. Ping Li and Roy Prosterman, "From Collective to Household Tenure: China and Elsewhere," op. cit., p. 289.

14. See Robin Burgess, "Land and Welfare: Theory and Evidence from China," London School of Economics Working Paper, 2001, available online at http://econ.Ise.ac.uk/staff/rburgess/wp/land_and_welfare2.pdf.

15. James Kai-sing Kung, "Equal Entitlement versus Tenure Security under a Regime of Collective Property Rights: Peasants' Preference for Institutions in Post-reform Chinese Agriculture," Journal of Comparative Economics, vol. 21, no. 1, 1995, pp. 82-111; James Kai-sing Kung, "Common Property Rights and Land Reallocations in Rural China: Evidence from a Village Survey," World Development, vol. 28, no. 4, 2000, pp. 701-719.

16. Ping Li and Roy Prosterman, "From Collective to Household Tenure: China and Elsewhere," op. cit., pp. 289-292, synthetically discuss these laws. 
Land Management Law of 1998 and the 2002 Law on Land Contracts in Rural Areas both reaffirmed the 30-year duration of land contracts, while the 2007 Property Law implicitly granted farmers perpetual rights, as it stated that farmers should retain their rights when the 30 years are over. Moreover, the Property Law for the first time defined farmers' rights as usufructuary, giving them stronger protection than under their previous regime as contractual rights. These provisions were completed by strict regulations on land readjustment or seizure. Land reallocation was forbidden except in the case of natural disaster, in which case it required acceptance by two-thirds of village representatives and township authorities. Land seizures by collective authorities in order to convert rural land to non-agricultural use was permitted, but must be for the "public interest," ${ }^{(17)}$ and farmers must get "appropriate compensation." ${ }^{(18)}$ Finally, since the 2002 Law on Land Contracts in Rural Areas, land contracts between local authorities and farmers must be made in writing, and if they are illegal or encroached upon, farmers have the right to judicial recourse. This law also gives and specifies land transfer rights for peasants. These new legal disposals have been repeatedly reaffirmed by the central authorities, especially in the seven consecutive Documents No. 1 from 2004 to 2010.

At the same time, two laws with important consequences for the functioning of local institutional arrangements on land have been passed. First, the 1998 revised Organic Law of Village Committees settled the organisation of village-level democracy, with village assemblies and elected village committees being put in charge of the management of rural land. This transfer of responsibilities to elected representatives was meant to reduce the arbitrary decision power of cadres and local CCP members. ${ }^{(19)}$ Second, the "Tax-for-fee" reform, ${ }^{(20)}$ experimented with first in Anhui Province at the end of the 1990s and then extended nationwide in 2001 (SCNPC Document No. 12) and 2003 (SCNPC Document No. 12), suppressed the various fees levied on peasants and turned them into a single tax of limited scope and level. The idea was to reduce the fiscal pressure on peasants and limit the incentives of local authorities to manipulate land. This first step in agricultural fiscal reform was followed by a radical move at the end of 2005, when the SCNPC decided to abolish agricultural taxes. At the same time, since the beginning of the 2000s, the Chinese state has multiplied the subsidies to which Chinese peasants are entitled. ${ }^{(21)}$ Over the last decade, Chinese farmers have not only experienced a rapid evolution of the land institutional framework, they have also seen a radical change in the rural taxation system.

\section{The last official limit: Land-use change}

Today, in 2010, according to prevailing laws, the only right farmers do not have is to change land use from agricultural to non-agricultural, due to two main obstacles.

First, according to the Constitution, agricultural land is collectively owned while non-agricultural land is state owned. Change of use then implies a change of owners, and a redefinition of farmers' contractual rights. This can happen, but is still mainly done by collective authorities and is possible only with great difficulty at the individual level. ${ }^{(22)}$

Second, since the 1990s, China has been committed to a policy of soil and farmland protection to reduce the loss of agricultural land to non-agricultural uses, or due to erosion. ${ }^{(23)}$

In 1994, the Regulations on the Protection of Basic Farmland were promulgated by the SCNPC to radically limit land use change and the decrease in agricultural soil. The principle was to identify "basic farmland," i.e. soil of aboveaverage quality, the use change for which must be approved by provincial or national authorities. The scope of these regulations was extended to all farmland in 1998 by the revised Land Management Law, which set a compulsory objective of no net decrease in farmland. Finally, these repeated concerns about the preservation of agricultural soil led the Ministry of Land and Resources, in the third National overall planning for land use (2006-2010), published in 2008, to set a bottom line of 1.8 billion $m u$ of arable land in China. All these regulations transferred the right to change land use from individual peasants to higher levels of the political hierarchy.

Moreover, to prevent soil erosion, an important policy of land preservation was initiated in the 1990s. The Water and Soil Conservation Law of 1991 first prohibited the exploitation of land with a slope above 25 degrees. A Sloped Land Conversion Program was then launched in 1999 to turn all sloped cropland into forest or grassland in order to prevent

17. 1998 Land Management Law, Article 2.

18. 2002 Law on Land Contract in Rural Areas, Article 16.

19. Jean Oi and Scott Rozelle, "Elections and Power: The Locus of Decision-Making in Chinese Villages," The China Quarterly, vol. 162, no. 1, 2000, pp. 513-539.

20. Ray Yep, "Can 'Tax-for-Fee' Reform Reduce Rural Tension in China? The Process Progress and Limitations," The China Quarterly, vol. 177, 2004, pp. 42-70.

21. For an up-to-date and synthetic account, see Wusheng Yu and Hans G. Jensen, "China's Agricultural Policy Transition: Impacts of Recent Reforms and Future Scenarios," Journal of Agricultural Economics, vol. 61, no. 2, 2010, pp. 343-368.

22. Chengri Ding, "Policy and Praxis of Land Acquisition in China," Land Use Policy, vol. 24 no. 1, 2007, pp. 1-3.

23. Erik Lichtenberg and Chengri Ding, "Assessing Farmland Protection Policy in China," Land Use Policy, vol. 25, no. 1, 2008, pp. 59-68. 
soil erosion. ${ }^{(24)}$ However, due to the decrease in arable land, now close to its bottom line, this program was suspended by the MLR in 2009. ${ }^{(25)}$

As a consequence, since the end of the 1990s, it has been very hard, if not impossible, for an individual farmer to turn agricultural land into non-agricultural productive use. This right remains in the hands of collective and state authorities. The goals of the central authorities have then been, since 1993 and especially during the last decade, extremely clear: farmers' rights must be extended and secured at the expense of collective authorities' discretionary powers, the only remaining limit to farmers' rights being that of land use change.

\section{The HRS today: Actual functioning}

As for the actual functioning of the HRS, the latest available evidence (as of 2010) is provided by the 2008 survey carried out by the Rural Development Institute (RDI). ${ }^{(26)}$

The primary conclusion is that the HRS is still operated in a very informal way, with national laws and regulations reaching rural villages only in small part. To mention two examples, in 2008, only one-third (32 percent) of farmers had the official documents made compulsory by the 2002 law, while 41.8 percent had no documentation at all. At the same time, and unsurprisingly, farmers had a poor knowledge and understanding of their rights. For example, in 2008, onethird ( 35.9 percent) of surveyed farmers had not heard of the 2002 law, while only slightly more than a quarter (28.7 percent) had heard of the 2007 Property Law.

However, the serie of central laws and Documents has still had an impact. The pace of land reallocations has decreased, while land markets seem to have developed. Indeed, the same survey indicates that roughly 15 percent of farmers transferred out their land in 2008, ${ }^{(27)}$ whereas another investigation on rural land markets carried out in 2002 showed that only 3.2 percent of farm households did so in 2001, and virtually none in 1996. ${ }^{(28)}$ As for administrative reallocations of land, a 2005 survey of the NBS and the World Bank specifically dedicated to this issue shows that the share of villages experiencing collective land reallocations has significantly decreased after the implementation of the 2002 Law on Land Contracts in Rural Areas, from 13.18 percent to 8.32 percent. ${ }^{(29)}$ It appears, then, that in the last decade, land allocation at the local level has increasingly been taking place through market rather than administrative transfers.

This evolution remains far from complete, however. The slight increase in land transfers does not necessarily indicate a development of market processes, as few transfers involve compensation or payment. ${ }^{(30)}$ Another significant development, much more detrimental to farmers, is that the development of the non-agricultural sector and of urbanisation, combined with the afore-mentioned regulations on farmland protection and soil preservation, has considerably increased the pressure on land as well as its value for non-agricultural uses. As land use change and its expected benefits can only be reaped by authorities that have the capacity to change land use, seizure of land has increased considerably, ${ }^{(31)}$ often with inadequate compensation for farmers. Just as land reallocation was arguably the main issue of the first two decades of the HRS, unilateral land seizure has emerged as the main problem today.

\section{The Household Responsibility System: Successes, shortcom- ings, and flexibility}

The rural reforms initiated around 1980 have been extremely successful. Whereas the average rural real income per capita was at the same level in 1978 as in 1956, ${ }^{(32)}$ it increased by 15 percent a year over the next six years. ${ }^{(3)}$ This success has been largely attributed to the new institutional framework prevailing after the introduction of the HRS. The reasons invoked will be briefly analysed in the first part of this section, as literature on this issue is extensive and literature reviews already numerous. However, despite a continuous increase in rural revenues, rural areas have benefited less from Chinese economic growth than urban ones since

24. For a synthetic account of these policies, see Futian Qu et al., "Sustainable natural resource use in rural China: Recent trends and policies," China Economic Review, forthcoming, doi:10.1016/j.chiec0.2010.08.005.

25. http://www.chinadaily.com.cn/china/2009-06/23/content_8314969.htm.

26. Roy Prosterman et al. "Secure Land Rights as a Foundation for Broad-Based Rural Development in China: Results and Recommendations from a Seventeen-Province Survey," National Bureau of Asian Research Special Report 18, 2009.

27. Ibid., p. 23.

28. Klaus Deininger and Songqing Jin, "The Potential of Land Rental Markets in the Process of Economic Development: Evidence from China," Journal of Development Economics, vol. 78, no.1, 2005, p. 251.

29. Klaus Deininger and Songqing Jin, "Securing property rights in transition: Lessons from implementation of China's rural land contracting law," Journal of Economic Behavior \& Organization, vol. 70, 2009, p. 30.

30. Roy Prosterman et al. "Secure Land Rights as a Foundation for Broad-Based Rural Development in China: Results and Recommendations from a Seventeen-Province Survey," op. cit., p. 24

31. Ibid., p. 24.

32. Ping Li and Roy Prosterman, "From Collective to Household Tenure: China and Elsewhere," op. cit., p. 284.

33. Shujie Yao, "Economic Development and Poverty Reduction in China over 20 Years of Reforms," Economic Development and Cultural Change, vol. 48, 2000, pp. 447-474. 
1985, and inequalities between urban and rural citizens have been steadily increasing. Shortcomings in the HRS system have also been invoked to account for this gap, and they will be analysed in the second part. Finally, central government policies aimed at improving the perceived dysfunction of land rights institutions have faced severe difficulties in grassroots villages, as local interests have a strong role in determining local arrangements, an aspect that will be examined in the third and last part of this section.

\section{The HRS vs collectivisation: The factors of success, and remaining shortcomings}

The tremendous success of the HRS in its first years was the subject of a wide range of literature in the second half of the 1980s and in the beginning of the 1990s. The main point of debate was to determine the respective importance of the consequences of changes in national policies, such as increasing prices for agricultural products and increasing supply of inputs, of changes in technology, and of institutional evolution. Indeed, one of the main criticisms raised against the socialist organisation of production, especially in agriculture, was the lack of incentives due to the absence of private appropriation of gains due to increased effort. Rural China in the reform era is then a perfect case study to verify the superiority and efficiency of markets. As a consequence, a huge empirical literature has developed on this topic in the case of China.

Theoretically, three main advantages can be expected from the introduction of the HRS and of market processes. First, they are likely to increase the effort provided by farmers, as they become the full "residual claimants" over their production. The second expected gain is an allocative one. If individuals have better information on the efficiency of soil uses and agricultural techniques, they can make better choices about crops and technologies than central planners. Finally, the spread of market processes and trade should allow farmers to receive the benefits of comparative advantages, and to allocate soils to their most productive uses.

As for the case of rural China, the empirical studies based on these theoretical arguments have recently been summarised and discussed by $\mathrm{Yu}$ Xiaohua and Zhao Guoqing. ${ }^{(34)}$ Since the beginning of the 1980s, an important body of literature has discussed the respective effects of changes in institutions, prices, inputs, and technology in the unprecedented success of Chinese agricultural reforms during the period 1978-1985. However, it remains undeniable that the diffusion of the HRS, that is to say the institutional dimension of reform, has had an extremely important effect.
Whatever the data or methodology used, the HRS is one of the two most important factors behind China's agricultural performance at the beginning of the 1980s, and it is widely acknowledged that the main direct consequences of the introduction of HRS were to give farmers residual claim over their production and increase the degree of productive choices, which increased individual effort on the one hand, and improved efficiency on the other.

The significant slow-down in the increase of rural incomes since 1985 has changed the main focus of researchers from the success of the HRS to its shortcomings. As mentioned above, two major rights remain, according to or despite central laws, in the hands of collective authorities. First, according to national laws and regulations, individual farmers do not have the right to change land use, which is a prerogative of political authorities. Second, despite repeated efforts by the central state since the mid-1980s to limit and then ban administrative transfers of land, all surveys carried out up to the late 2000s show that local collective authorities have generally retained their (illegal) power to transfer land use rights among farmers. As a result, Chinese farmers do not enjoy the right to change the use of their land, and they have only limited and tentative rights to transfer their plots. These two constraints have detrimental consequences for Chinese farmers and overall development along two dimensions. First, they directly affect agricultural performance. Second, they have a direct impact on structural change by preventing land and labour from moving out of agriculture. It should also be noted that these limits on farmers' individual rights affect their behaviour through two channels: first, they directly limit what they can do with their land, and second, the fact that land transfers and land use changes can be decided unilaterally by collective authorities creates insecurity for farmers, as they could see their land rights unexpectedly jeopardised by village leaders. The empirical literature on these issues is reviewed below.

\section{Consequences on agricultural development: Land allocation}

The first impact of imperfect land rights institutions is, of course, directly on agricultural development. This section reviews the empirical evidence in the Chinese case.

The first of the remaining limits on farmers' land use rights is that on land transfers. The transfer of household land-use

34. Xiaohua Yu and Guoging Zhao, "Chinese Agricultural Development in 30 years: A Literature Review," Frontiers of Economics in China, vol. 4, no. 4, 2009, pp. 633-648. 
rights, through rental or sale, has been officially allowed by the central government since the mid-1980s. However, for reasons that will be developed later, rural land is still generally allocated through administrative or collective processes, and actual individual land transfers and land markets have remained quite limited. The main expected gain of such transfers is the transfer of land from less productive to more productive households.

Lohmar, Zhang, and Somwaru ${ }^{(35)}$ use a 1998 survey on 825 peasant households distributed in 30 villages to verify whether households who take on more land have a systematically higher productivity than ones that do not. They compute an agricultural production function for every single land plot, including a dummy indicating whether the farming household rents additional land. This dummy has a positive coefficient showing that households renting additional land have a higher marginal productivity than those that do not. This indicates that rental markets do actually allow land to be transferred to more productive households.

Benjamin and Brandt ${ }^{(36)}$ take a different approach. Using data gathered in 30 villages of Hebei and Liaoning provinces, they find an inverse relationship between a household's farm size and labour productivity, which means that too much labour is used on small farms compared to larger ones, ${ }^{(37)}$ with an estimated 30 days of work per year "wasted" on medium and small farms. The existence of off-farm work opportunities and administrative reallocations alleviate, but do not cancel out, this allocative inefficiency.

Deininger and Jin ${ }^{(38)}$ use a four-year panel dataset on agricultural households in three of the poorest provinces (Guizhou, Hunan, Yunnan) in 1997, 1998, 1999, and 2001. They first estimate an "agricultural production ability" at the household level, and then show that administrative processes of land allocation lead to land transfers from households with more land and lower productivity to those with less land and higher productivity, but that market exchanges are more efficient. Immediately removing constraints on land rentals at current prices could lead to a 3.5 percent gain in production.

Continuing in that direction, Jin and Deininger ${ }^{(39)}$ use a fouryear panel dataset (2001-2004) of 8,000 households in about 800 villages to further investigate the effects of land rentals. They confirm that individual transfers of land lead to an efficiency-enhancing equalisation of production factors across households.

These results have been confirmed by a survey carried out in 2000 and 2002 by Feng, Heerink, Ruben, and $\mathrm{Qu}^{(40)}$ on 52 farm households in northern Jiangxi Province, which shows that households renting additional land actually achieve higher productivity on their plots.
A series of empirical studies has thus shown that the development of land rental markets made possible by individual land transfer rights can potentially have important effects on agricultural efficiency. Investment is another channel through which the development of individual land transfer rights at the expense of administrative reallocation could have a positive impact on agricultural development.

\section{Consequences on agricultural development: Investment}

As Chinese farmers' land transfer rights are limited, land allocation remains driven mainly by collective authorities. This naturally creates uncertainty about the actual duration of land-use rights, and can have the direct consequence of reducing investment.

The most detailed study on this issue is provided by Jacoby, $\mathrm{Li}$, and Rozelle, ${ }^{(4)}$ who investigate how a household time horizon over specific plots affects the use of fertilizer. Using the same survey as the afore-mentioned study by Benjamin and Brandt, ${ }^{(42)}$ they use the fact that the degree of land rights security can vary according to village-level policies and land plot and household characteristics to compute a "hazard function" that indicates how long a household can expect to keep a given plot. As expected, the use of organic fertilizer, which has lasting effects on soil quality, is reduced when there is a higher risk of losing a specific plot, whereas this shortened time horizon has no impact on chemical fertilizers, the benefits of which do not last beyond a season. However, while significant, the efficiency cost of land rights insecurity is not very important: the authors estimate that se-

35. Bryan Lohmar et al., "Land Rental Market Development And Agricultural Production In China," paper presented during the 2001 Annual meeting of the American Agricultural Economics Association, 5-8 August, Chicago.

36. Dwayne Benjamin and Loren Brandt, "Property Rights, Labour Markets, and Efficiency in a Transition Economy: The Case of Rural China," The Canadian Journal of Economics / Revue canadienne d'Économie, vol. 35, no. 4, 2002, pp. 689-716.

37. Large farms are defined as those in the 90th percentile, and thus cover an area exceeding $33 \mathrm{mu}$.

38. Klaus Deininger and Songqing Jin, "The Potential of Land Rental Markets in the Process of Economic Development: Evidence from China," op. cit.

39. Songqing Jin and Klaus Deininger, "Land Rental Markets in the Process of Rural Structural Transformation: Productivity and Equity Impacts from China," Journal of Comparative Economics, vol. 37, no. 4, 2009, pp. 629-646.

40. Shuyi Feng et al., "Land rental market, off-farm employment and agricultural production in Southeast China: A plot-level case study," China Economic Review, vol. 21, no. 4, December 2010, pp. 598-606.

41. Hanan Jacoby et al., "Hazards of Expropriation: Tenure Insecurity and Investment in Rural China," American Economic Review, vol. 92, no. 5, 2002, pp. 1420-1447.

42. Dwayne Benjamin and Loren Brandt, "Property Rights, Labour Markets, and Efficiency in a Transition Economy: The Case of Rural China," op. cit. 
curing land tenure for 15 or 30 years would increase land value by less than 1 percent.

As for Deininger and Jin, ${ }^{(43)}$ they use their survey on 1,001 households in $2001^{(44)}$ to study the consequences of land rights security on investment. They make use of the fact that Guizhou Province in 1994 enacted an experimental policy labelled the "two-nos" policy, for "no land increase for new population, no land decrease for reduced population." (45) They then compare the investment behaviours of households in Guizhou with those of farmers in the neighbouring provinces of Yunnan and Hunan, which did not implement this policy. They also compare investment behaviours in villages that did and did not implement the "two-nos," regardless of province-level policies. They find that, as expected, a higher level of land rights security leads to higher investment, and the effect is especially strong when land can be transferred - that is to say, when land is a liquid asset.

These two studies confirm that land rights insecurity has a constraining impact on agricultural investment. Combined with the relative allocative inefficiency of collective reallocations, this can partly explain why the rate of increase in agricultural productivity has been slowing down.

\section{Consequences on structural change: Labour}

Structural change represents the transfer of factors of production, especially labour, from traditional activities to modern sectors. It is a critical determinant of economic development. Rural land rights have consequences on the sectoral allocation of two production factors: labour and, of course, land.

The remaining limitations and constraints on individual transfer rights have consequences on labour allocation, directly, on the one hand, because individuals cannot freely and easily transfer out their land if they want to leave agriculture, and indirectly, on the other hand, because of the insecurity created by administrative reallocations.

The first argument is formalised by Yang. ${ }^{\left({ }^{46)}\right.}$ The idea is that since land cannot be leased or sold, leaving agriculture means the uncompensated loss of the stream of income associated with farming. The absence of land transfer rights then adds cost when an individual chooses to try for an offfarm job, and directly constrains labour allocation and structural change.

This hypothesis is empirically checked by Rozelle, Guo, Shen, Hughart, and Giles. ${ }^{(47)}$ Their analysis of a survey of 200 villages in 1995 shows that the existence of land rental markets in a village is positively correlated with migration behaviours, a result suggesting that migration is easier when there is a possibility of transferring out land.

This first direct effect of the absence of land transfer rights on labour allocation is reinforced by the threat of land reallocation by collective authorities. Indeed, workers allocating more of their time to off-farm activities are likely to see their land rights jeopardised and transferred to those who remain more involved in agriculture.

Lohmar ${ }^{(48)}$ uses a survey carried out in 1995 among 787 households in 31 villages of Hebei and Liaoning provinces ${ }^{(49)}$ to estimate the impact of land rights insecurity on households' off-farm labour participation. He uses the proportion of households affected by past village-wide reallocations as indicating land rights insecurity, and finds an impact on the probability of being locally self-employed, while correlations with local employed work or out-migration, as well as with the duration of off-farm occupation, are all insignificant. The effect on labour allocation thus seems to be small.

As for Mullan, Grosjean, and Kontoleon, ${ }^{\left({ }^{(5)}\right)}$ they use data on 571 households in Ningxia and Guizhou provinces and find that a higher level of perceived insecurity (self-reported probability of having to face a land reallocation) has a negative impact on migration decisions, while the possibility of leasing land has no significant effect.

Finally, the work of de la Rupelle, Deng, $\mathrm{Li}$, and Vendryes ${ }^{(51)}$ uses the Chinese Household Income Project (CHIP) dataset on rural areas, covering 37,969 people in 2002. They measure the impact of a household's exposure

43. Klaus Deininger and Songqing Jin, "The Impact of Property Rights on Households' Investment, Risk Coping, and Policy Preferences: Evidence from China," Economic Development and Cultural Change, vol. 51, no. 4, 2003, pp. 851-882.

44. Klaus Deininger and Songqing Jin, "The Potential of Land Rental Markets in the Process of Economic Development: Evidence from China," op. cit.

45. Klaus Deininger and Songqing Jin, "The Impact of Property Rights on Households' Investment, Risk Coping, and Policy Preferences: Evidence from China,", op. cit., p. 854.

46. Dennis Tao Yang, "China's Land Arrangements and Rural Labor Mobility," China Economic Review, vol. 8, no. 2, 1997, pp. 101-115.

47. Scott Rozelle et al., "Leaving China's Farms: Survey Results of New Paths and Remaining Hurdles to Rural Migration," The China Quarterly, vol. 158, no. 1, 1999, pp. 367-393.

48. Bryan Lohmar, "Land Tenure Insecurity and Labor Allocation in Rural China," paper presented during the 1999 Annual meeting of the American Agricultural Economics Association, 8-11 August, Nashville.

49. This survey is also used by Dwayne Benjamin and Loren Brandt, "Property Rights, Labour Markets, and Efficiency in a Transition Economy: The Case of Rural China," op. cit., and Hanan Jacoby et al., "Hazards of Expropriation: Tenure Insecurity and Investment in Rural China," op. cit.

50. Katrina Mullan et al., "Land Tenure Arrangements and Rural-Urban Migration in China," World Development, vol. 39, no. 1, 2011, pp. 123-133.

51. De la Rupelle et al., "Land Rights Insecurity and Temporary Migration in Rural China," PSE Working Papers 2009-42, Paris School of Economics, 2009. 
to land rights insecurity on the work time allocated to migration. Land rights insecurity is indicated by the interaction between the existence of collectively retained "flexible land" in a village, measuring land rights insecurity at the village level, and the proportion of relatively secure "grain ration land" in households' land holdings, giving the exposure of household land to overall insecurity. They find a negative impact on migration, but this effect, while significant, remains small.

Empirical evidence on the constraining impact of land rights insecurity and of the absence of land transfer rights remain scant, and when a constraining effect is found, it remains minimal.

\section{Consequences on structural change: Land}

As mentioned earlier, land use change remains very difficult and strictly framed in China due to a series of national regulations for the protection of farmland and the environment. However, this has not prevented agricultural land from being converted into urban or industrial use. The development of satellite imagery has allowed detailed study of this evolution ${ }^{(52)}$ and has revealed a very significant expansion of urban or industrial use of land at the expense of agriculture. $\mathrm{Na}$ tional laws and regulations do not seem to have significantly affected land use change, except for the "grain-for-green" policy, which has led to an increase in grassland and forest coverage. Agricultural land is then jeopardised from both sides: by environmental as well as urban development concerns. Using satellite imagery data, Deng, Huang, Rozelle, and Uchida ${ }^{(53)}$ have shown that farmers and rural authorities were still able, at least up to 2000, to compensate for land loss due to urban expansion and environmental protection. Even if the newly exploited soils are of inferior quality, the increase in quantity has allowed maintenance of overall land endowments. However, most recent studies, using data from the land use change monitoring system of the MLR and from agricultural censuses, find a slight decline in agricultural soil before 2000 and a significant acceleration in this decline afterwards, mainly due to ecological programs. ${ }^{\left({ }^{4}\right)}$ Under the continuing pressure of structural change on the one hand and ecological concerns on the other, it is quite likely that this trend will continue in the foreseeable future, as shown by the simulations using the Chinagro welfare model. ${ }^{(55)}$

Soil preservation policies did not, then, prevent land from being transferred from agricultural to non-agricultural uses, but in themselves exacerbated the scarcity of agricultural soil, an evolution that is expected to continue in the coming years.
While the introduction of the HRS was extremely successful during the first half of the 1980s, limitations on farmers' rights acted as a constraint on agricultural development and structural change. This raises the question of the reasons behind the fact that land rights arrangements at the local level can diverge significantly from the central authorities' will. In fact, rural land rights arrangements influenced by national laws are also the result of the interests of local leaders and villagers at the grassroots level.

\section{Land rights institutions flexibility: The interests of local authorities}

Local flexibility in arrangements on rural land is acknowledged by the Organic Law of the Village Committees, which gives village leaders responsibility for land management. Their interests therefore play a crucial role in the definition of land use rights. Rozelle ${ }^{(56)}$ identifies three of them: private interests, administrative duties, and economic efficiency.

The study of Rozelle and $\mathrm{Li}^{(57)}$ uses a sample of 184 villages surveyed in 1996 to specifically investigate how village leaders use land rights to achieve these various objectives. Their leading idea is that the more benefits, personal or collective, a village leader can expect from land manipulation, the more incentive he has to reallocate land and thus to maintain land rights insecurity, measured by the number of past land reallocations. As expected, they find that the higher the benefits associated with the control of the village economy, the higher the level of insecurity.

Brandt, Rozelle, and Turner ${ }^{(58)}$ follow the same kind of methodology with a survey carried out in 1995 and 1996 in 215 villages. They show that land reallocations can be sub-

52. The main studies using these data are Jiyuan Liu et al., "Study on Spatial Pattern of Land-Use Change in China during 1995-2000," Science in China Series D: Earth Sciences, vol. 46, no. 4, 2003, pp. 373-384; Huang Deng et al., "Growth, Population and Industrialization, and Urban Land Expansion of China," Journal of Urban Economics, vol. 63, no. 1, 2008, pp. 96-115; Jiyuan Liu et al., "Spatial Patterns and Driving Forces of Land Use Change in China during the Early 21st Century," Journal of Geographical Sciences, vol. 20, no. 4, 2010, pp. 483-494.

53. Huang Deng et al., "Cultivated Land Conversion and Potential Agricultural Productivity in China," Land Use Policy, vol. 23, no. 4, 2006, pp. 372-384.

54. Futian Qu et al., "Sustainable natural resource use in rural China: Recent trends and policies," op. cit.

55. Günther Fischer et al., "China's agricultural prospects and challenges," SOW-VU report for the European Union, 2007.

56. Scott Rozelle, "Decision-Making in China's Rural Economy: The Linkages between Village Leaders and Farm Households," The China Quarterly, vol. 137, 1994, pp. 99-124.

57. Scott Rozelle and Guo Li, "Village Leaders and Land-Rights Formation in China," The American Economic Review, vol. 88, no. 2, 1998, pp. 433-438.

58. Loren Brandt et al., "Local Government Behavior and Property Right Formation in Rural China," Journal of Institutional and Theoretical Economics, vol. 160, 2004, pp. 627-662. 
stitutes for missing markets, and can be used by village leaders to maintain equity across households, but that village leaders also respond to political demands such as quota fulfilment as well as to rent-seeking activities.

Empirical studies therefore tend to show that land rights institutions are at least partly shaped locally, by village leaders pursuing more or less selfish benefits. However, the three aforementioned studies examined the situation of Chinese villages before 1998, that is, before the second wave of legislative and regulatory activity on land rights issues. The role of village leaders today in shaping land rights therefore remains unclear.

\section{Land rights institutions flexibility: The interests of farmers}

Due to the expected benefits of secure and extended rights, it seems obvious that farmers would like to have land rights extended and secured as much as possible. However, all surveys on farmers' preferences conclude that there is no general or unequivocal preference for more private, extended, or secure land rights.

The Rural Development Institute has been conducting surveys on land rights issues and farmers' preferences since $2000 .{ }^{(59)}$ For example, in $2004,{ }^{(60)}$ a huge majority of farmers (between 80 percent and 90 percent) were in favour of acquiring the right to lease land. However, only 48 percent (vs. 39 percent) were in favour of acquiring the right to transfer their entire 30-year land use rights, while a minority (29.5 percent vs 49.5 percent) favoured the possibility of mortgaging land. The following surveys show a continuous increase in support for extended and secure rights, but as of 2008 , on the issue of administratively-led land readjustments, 45 percent of farmers declared that they opposed the practice of land readjustments, against 38.3 percent in 2001. ${ }^{(6) 1}$ The support for secure land rights is therefore increasing but not overwhelming.

The works of James Kung have been dedicated to the same issues. In 1993, ${ }^{(62)}$ he carried out a first survey on 400 peasant households in Hunan and Sichuan provinces, especially focused on existing and desired institutional arrangements on land, and found a great diversity in the extent and security of rights granted to households, and an even greater variation in farmers' preferences. For example, to the general question "Where do you think ownership should reside?", there was only one county where there was significant support (16 percent of respondents) for individual ownership. In all other places, land ownership was seen as having to re- main in the hand of collective or state authorities. The author concluded that in a land-scarce, labour-abundant economy, farmers preferred to be sure that periodic collective readjustments of land would provide them with land holdings in accordance with their changing family needs.

Kung and $\mathrm{Liu}^{(33)}$ replicated this investigation in 1994 with roughly the same results, with a good majority of farmers (62 percent) opposing the state policy of stabilising land plots for 30 years. They showed that support for collective land readjustment was strongest in places where the economy remained mostly agricultural, and was higher among the poorest households. Their interpretation was that farm households in this context saw land as an insurance device that must evolve according to family changes, and that this objective was better attained through administrative rather than market allocation processes. The authors also stressed the egalitarian spirit of post-Maoist rural society.

Using an 80-village survey of eight counties in four provinces carried out in 1994, Kung ${ }^{(64)}$ showed that land reallocations were more frequent and larger where land was more valuable, that is to say, where land was relatively scarce and where there were fewer off-farm opportunities. Land readjustments were then predominantly based on demographic evolution and on attempts to maintain egalitarian distribution.

In 2002, Kung ${ }^{(5)}$ enquired more precisely into the determinants of conflicting interests between households. He used

59. The four waves are Roy Prosterman et al., "Implementation of 30-Year Land Use Rights for Farmers Under China's 1998 Land Management Law: An Analysis and Recommendations Based on a 17 Province Survey," RDI Reports on Foreign Aid and Development 105, 2000; Brian Schwarzwalder et al., "An Update on China's Rural Land Tenure Reforms: Analysis and Recommendations Based on a Seventeen-Province Survey," Columbia Journal of Asian Law, vol. 16, no. 141, 2002, pp. 144-225; Keliang Zhu et al., "The Rural Land Question in China: Analysis and Recommendations Based on a SeventeenProvince Survey," New York University Journal of International Law and Politics, vol. 38, no. 4, 2006, pp. 761-840; Roy Prosterman et al., "Secure Land Rights as a Foundation for Broad-Based Rural Development in China: Results and Recommendations from a Seventeen-Province Survey," op. cit.

60. See Roy Prosterman et al., "Implementation of 30-Year Land Use Rights for Farmers Under China's 1998 Land Management Law: An Analysis and Recommendations Based on a 17 Province Survey," op. cit., p. 20.

61. See Roy Prosterman et al., "Secure Land Rights as a Foundation for Broad-Based Rural Development in China: Results and Recommendations from a Seventeen-Province Survey," op. cit., p. 15.

62. James Kung, "Equal Entitlement versus Tenure Security under a Regime of Collective Property Rights: Peasants' Preference for Institutions in Post-reform Chinese Agriculture," op. cit.

63. James Kung and Shouying Liu, "Farmers' Preferences Regarding Ownership and Land Tenure in Post-Mao China: Unexpected Evidence from Eight Counties," The China Journal, vol. 38, 1997, pp. 33-63.

64. James Kung, "Common Property Rights and Land Reallocations in Rural China: Evidence from a Village Survey," op. cit.

65. James Kung, "Choice of Land Tenure in China: The Case of a County with Quasi-Private Property Rights," Economic Development and Cultural Change, vol. 50, no. 4, 2002, pp. 793-817. 
a 300-household survey of four villages in Guizhou Province that had implemented an experimental policy of completely halting land readjustments. His first finding was that while support for this policy was majoritary ex ante, it significantly decreased ex post. His investigation into farmers' preferences and their link with household characteristics clearly supported the view that halting land readjustments has important distributive affects, and that only potential winners support this practice. To give an example, households with more dependent members favour land reallocations, as they are potential gainers.

Finally, using data from a survey carried out by the Ministry of Agriculture in 1998 covering 824 farmers households in six provinces, Kung ${ }^{(6)}$ showed that off-farm workers tended to rent out land, as might be expected, and that the increase in off-farm opportunities therefore acted as a push factor on the development of land markets. This further tends to indicate that overall economic development, especially the increase in off-farm activities, has a direct impact on farmers' use of their land, and therefore on their preferences regarding land institutions.

Studies by the Rural Development Institute and James Kaising Kung therefore tend to show, contrary to expectation, that there is a significant diversity in farmers' preferences regarding land rights institutional arrangements, and that peasant households, especially in a context of high reliance on agricultural production, do not have clear-cut preferences for more extended, more secure, or more private land rights. Among the various explanations proposed, the fact that $\mathrm{Chi}$ nese rural citizens have lost the limited social safety net and public services they enjoyed during the collectivist era ${ }^{(6)}$ is likely to play an important role in increasing the attractiveness of collective and more-or-less egalitarian processes of land allocation. ${ }^{(68)}$

\section{Conclusion}

The effects of the reforms introduced in rural China since 1978 have led to one of the greatest victories against poverty the world has ever experienced. In a handful of years, from 1978 to 1985, China's rural incomes rose as never before. Most of this success is attributed to the introduction and spread of the Household Responsibility System (HRS), which still constitutes the institutional framework for rural land today.

The founding of the HRS and its variation across time and location provides one of the best case studies on the consequences and determinants of institutional arrangements over land. The incentive effect of granting Chinese farmers freedom over production choices and residual claims over their land production has proved extremely strong. However, the remaining limits on land rights, and especially the fact that land transfers are mainly carried out through administrative procedures rather than market processes, still act as a constraint on agricultural development and structural change, despite the repeated effort of the central state to extend and secure farmers' rights and to limit local authorities' involvement in land management.

Probably the most interesting characteristic of the HRS, however, is its great flexibility, which reveals how institutions respond to the contradictory interests of political leaders and peasant households. In each Chinese village, the prevailing institutional arrangement over land is the result of a complex interaction between central state regulations, the behaviour of local leaders, and the preferences of grassroots residents. The optimality of land rights arrangements, as well as the fulfilment of the desires of China's rural citizens, cannot be assessed globally, but constitute a local issue. •
66. James Kung, "Off-Farm Labor Markets and the Emergence of Land Rental Markets in Rural China," Journal of Comparative Economics, vol. 30, no. 2, 2002, pp. 395-414.

67. For a recent and synthetic discussion of this issue, see Xiaobo Zhang and Ravi Kanbur "Spatial inequality in education and health care in China," China Economic Review, vol. 16, no. 2, 2005, pp. 189-204.

68. See Robin Burgess, "Land and Welfare: Theory and Evidence from China," op. cit. 


\section{Articles}

Appendix. Chronological index of laws and regulations mentioned in the text, with sources (in Chinese unless stated otherwise)

\begin{tabular}{|c|c|}
\hline Year & Index \\
\hline 1950 & $\begin{array}{l}\text { Land Reform Law } \\
\text { http://www.law110.com/law/country/1059.htm }\end{array}$ \\
\hline 1955 & $\begin{array}{l}\text { CCPCC Decisions on Agricultural Production } \\
\text { http://news.xinhuanet.com/ziliao/2004-12/28/content_2388255.htm } \\
\text { R. Bowie and John K. Fairbank, Communist China 1955-1959: Policy Documents with Analysis, Cambridge, Harvard University } \\
\text { Press, 1966, pp. 106-116 (in English) }\end{array}$ \\
\hline 1956 & $\begin{array}{l}\text { Charter of Agricultural Production Cooperatives } \\
\text { http://law.148365.com/2534.html }\end{array}$ \\
\hline 1956 & $\begin{array}{l}\text { Charter of Advanced Agricultural Production Cooperatives } \\
\text { http://law.148365.com/2525.html }\end{array}$ \\
\hline 1961 & $\begin{array}{l}\text { Sixty Articles on Agriculture } \\
\text { http://www.weiweikl.com/sxzb18.htm }\end{array}$ \\
\hline 1962 & $\begin{array}{l}\text { Sixty Articles on Agriculture (revised version) } \\
\text { http://www.law110.com/law/other/19156.htm }\end{array}$ \\
\hline 1978 & $\begin{array}{l}\text { Communiqués of the Third Plenary Session of the CCP Eleventh Central Committee } \\
\text { http://baike.baidu.com/view/1975390.htm } \\
\text { de Bary(1999) et al., Sources of Chinese Tradition, 2nd ed., vol. 2, New York Chichester, Columbia University Press, pp. 485- } \\
491 \text { (in English) }\end{array}$ \\
\hline 1980 & $\begin{array}{l}\text { CCPCC Document No. } 75 \\
\text { http://news.xinhuanet.com/ziliao/2005-02/04/content_2547020.htm }\end{array}$ \\
\hline 1982 & $\begin{array}{l}\text { PRC Constitution } \\
\text { http://news.xinhuanet.com/newscenter/2004-03/15/content_1367387.htm } \\
\text { http://english.peopledaily.com.cn/constitution/constitution.html (in English) }\end{array}$ \\
\hline 1982 & $\begin{array}{l}\text { CCPCC Document No. } 1 \\
\text { http://law.lawtime.cn/d535574540668.html/pos=0 }\end{array}$ \\
\hline 1983 & $\begin{array}{l}\text { CCPCC Document No. } 1 \\
\text { http://www.yihaowenjian.com/index.php/newshow/jiangchuanmei/1/cn/725,248/248.html }\end{array}$ \\
\hline 1984 & $\begin{array}{l}\text { CCPCC Document No. } 1 \\
\text { http://www.yihaowenjian.com/index.php/newshow/jiangchuanmei/1/cn/726,248/248.html }\end{array}$ \\
\hline 1985 & $\begin{array}{l}\text { CCPCC Document No. } 1 \\
\text { http://www.yihaowenjian.com/index.php/newshow/jiangchuanmei/1/cn/727,248/248.html }\end{array}$ \\
\hline 1986 & $\begin{array}{l}\text { CCPCC Document No. } 1 \\
\text { http://www.yihaowenjian.com/index.php/newshow/jiangchuanmei/1/cn/728,248/248.html }\end{array}$ \\
\hline 1986 & $\begin{array}{l}\text { Land Management Law } \\
\text { http://www.chinacourt.org/flwk/show.php?file_id=5349 }\end{array}$ \\
\hline 1991 & $\begin{array}{l}\text { Water and Soil Conservation Law } \\
\text { http://www.chinawater.net.cn/law/W01.htm } \\
\text { http://www.china.org.cn/environment/2007-08/20/content_1034358.htm (in English) }\end{array}$ \\
\hline 1993 & $\begin{array}{l}\text { CCPCC Document No. } 11 \\
\text { http://law.lawtime.cn/d491423496517.html/pos=0 }\end{array}$ \\
\hline 1994 & $\begin{array}{l}\text { Regulations on the Protection of Basic Farmland } \\
\mathrm{http}: / / \text { www.yangshuo.gov.cn/lawweb/wjk/flfg/013.htm }\end{array}$ \\
\hline 1997 & $\begin{array}{l}\text { CCPCC Document No. } 16 \\
\text { http://www.law-lib.com/lawhtm/1997/66092.htm }\end{array}$ \\
\hline 1998 & $\begin{array}{l}\text { Revision of the } 1986 \text { Land Management Law } \\
\text { http://www.law-lib.com/law/law_view.asp?id=419 } \\
\text { http://www.china.org.cn/english/environment/34345.htm (in English) }\end{array}$ \\
\hline 1998 & $\begin{array}{l}\text { Revision of the } 1988 \text { Organic Law of Village Committees } \\
\text { http://www.jincao.com/fa/01/law01.12.htmhttp://www.china.org.cn/english/government/207279.htm (in English) }\end{array}$ \\
\hline
\end{tabular}




\begin{tabular}{|c|c|}
\hline Year & Index \\
\hline 1998 & $\begin{array}{l}\text { Revision of the } 1994 \text { Regulations on the Protection of Basic Farmland } \\
\text { http://news.xinhuanet.com/zhengfu/2003-08/29/content_1053423.htm } \\
\text { http://gtzyzcfl.com.cn/english/news.asp?id=7697 (in English) }\end{array}$ \\
\hline 2001 & $\begin{array}{l}\text { SCNPC Document No. } 5 \\
\text { http://news.eastday.com/eastday/zfgb/gwy/userobject1ai14906.html }\end{array}$ \\
\hline 2002 & $\begin{array}{l}\text { Law on Land Contracts in Rural Areas } \\
\text { http://news.xinhuanet.com/zhengfu/2002-08/30/content_543847.htm } \\
\text { http://www.gov.cn/english/laws/2005-10/09/content_75300.htm (in English) }\end{array}$ \\
\hline 2002 & $\begin{array}{l}\text { Regulations on the Grain-for-Green Program } \\
\text { http://news.xinhuanet.com/zhengfu/2002-12/25/content_669840.htm }\end{array}$ \\
\hline 2003 & $\begin{array}{l}\text { SCNPC Document No. } 12 \\
\text { http://www.mos.gov.cn/gjb/gjb_display.jsp?mid=20061228023390 }\end{array}$ \\
\hline 2004 & $\begin{array}{l}\text { CCPCC Document No. } 1 \\
\text { http://www.yihaowenjian.com/index.php/newshow/jiangchuanmei/1/cn/729,248/248.html }\end{array}$ \\
\hline 2005 & $\begin{array}{l}\text { CCPCC Document No. } 1 \\
\text { http://www.yihaowenjian.com/index.php/newshow/jiangchuanmei/1/cn/730,248/248.html }\end{array}$ \\
\hline 2005 & $\begin{array}{l}\text { SCNPC Decision Concerning the Abolition of the Regulations on Agricultural Taxation } \\
\text { http://www.gov.cn/flfg/2005-12/30/content_142025.htm }\end{array}$ \\
\hline 2006 & $\begin{array}{l}\text { CCPCC Document No. } 1 \\
\text { http://www.yihaowenjian.com/index.php/newshow/jiangchuanmei/1/cn/731,248/248.html }\end{array}$ \\
\hline 2007 & $\begin{array}{l}\text { CCPCC Document No. } 1 \\
\text { http://www.yihaowenjian.com/index.php/newshow/jiangchuanmei/1/cn/732,248/248.html }\end{array}$ \\
\hline 2007 & $\begin{array}{l}\text { Property Law } \\
\text { http://www.law-lib.com/law/law_view.asp?id=193400 } \\
\text { http://www.lehmanlaw.com/resource-centre/laws-and-regulations/general/property-rights-law-of-the-peoples-republic-of- } \\
\text { china.html (in English) }\end{array}$ \\
\hline 2008 & $\begin{array}{l}\text { CCPCC Document No. } 1 \\
\text { http://www.yihaowenjian.com/index.php/newshow/jiangchuanmei/1/cn/733,248/248.html }\end{array}$ \\
\hline 2008 & $\begin{array}{l}\text { Ministry of Land and Resources National Overall Planning for Land Use (2006-2020) } \\
\text { http://www.mlr.gov.cn/xwdtjrxw/200810/t20081024_111040.htm }\end{array}$ \\
\hline 2009 & $\begin{array}{l}\text { CCPCC Document No. } 1 \\
\text { http://www.yihaowenjian.com/index.php/newshow/jiangchuanmei/1/cn/734,248/248.html }\end{array}$ \\
\hline 2010 & $\begin{array}{l}\text { CCPCC Document No. } 1 \\
\text { http://news.xinhuanet.com/politics/2010-01/31/content_12907829.htm }\end{array}$ \\
\hline
\end{tabular}

